\title{
Dampak Konversi Dalam UUPA Terhadap Status Tanah Adat Di Bali
}

\author{
I Made Suwitra \\ Fakultas Hukum Universitas Warmadewa Denpasar \\ Jl. Terompong No. 24 Tanjung Bungkak Denpasar \\ madesuwitra@yahoo.co.id
}

\begin{abstract}
The stipulation of the conversion in UUPA (Agrarian Basic Laws), on the one hand is meant to guarantee that there is a law of land ownership which was mostly unsure before, especially for those who individually own their land hereditarily without formal or legal document. Conversion, on the other hand can affect that some traditional land which is informally owned before can be owned by right. The next effect is that the communal and religious duties in the form of "ayahan" which is attached to the land before disappears and changes into secular, private ownership. Beside that, traditional land belonging to traditional villages becomes less and if this condition is not handled or taken care of, it can threaten the traditional village itself. It seems that the anxiety has just been newly realized so that it brings conflict for the land ownership in Bali and this problem continuous until now and even can be seen in the villages in the traditional villages in every regency in Bali.
\end{abstract}

Key words : conversion, traditional land, land ownership conflict

\begin{abstract}
Abstrak
Penawaran/perjanjian dari konversi UUPA (Dasar Hukum Agraria), di satu pihak ditujukan pada adanya jaminan terhadap kepemilikan tanah yang sebelumnya masih diragukan kepemilikannya, terutama ditujukan pada mereka yang memiliki tanah secara turun temurun atau hanya diwariskan saja tanpa adanya bukti kelengkapan surat atau dokumen hukum yang berlaku. Konversi (Balik Nama), di sisi yang lain dapat mempengaruhi kepemilikan beberapa tanah yang secara tradisional masih berstatus dimiliki secara hak. efek lain adalah tugas masyarakat dan agama dalam bentuk "ayahan" yang telah terlampir pada tanah sebelum dihilangkan dan diubah menjadi kepemilikan privat/pribadi. Selain itu, pembagian tanah secara tradision akan menjadi berkurang, dan malah akan membahayakan penduduk desa itu sendiri. Permaslahan baru ini yang sepertinya baru akan disadari, seperti yang terjadi pada kasus sengketa kepemilikan tanah di Bali yang masalahnya pun masih berlangsung hingga saat ini, dan juga dapat dilihat di beberapa daerah dan wilayah-wilayah tradisional di Bali.
\end{abstract}

Kata kunci : konversi, tanah adat, konflik pertanahan. 


\section{Pendahuluan}

Pemilikan tanah awalnya hanya didasarkan pada penguasaan fisik berdasarkan accupatio terhadap tanah yang tergolong "res nullius" artinya secara ipso pacto ada hubungan secara riil antara tanah dengan subjek pemegang haknya. Setelah diundangkannya Undang-undang Nomor 5 Tahun 1960 tentang Peraturan Dasar Pokok-Pokok Agraria (UUPA), diharapkan pemegang hak tadi mendaftarkan tanahnya untuk memperoleh bukti hak milik berupa sertifikat tanah melalui konversi, sehingga dapat menjamin kepastian hukum terhadap pemilikan tanah.

Di Bali sebagian besar tanah dalam wilayah desa adat kecuali tanah individu penuh merupakan tanah adat baik yang dikuasai secara komunal maupun secara individual. Penguasaan dan pemilikan tanah menurut hukum adat sampai saat ini masih diakui sepanjang belum lengkap mendapat pengaturan dalam HTN, (lihat Pasal 56, 58 UUPA). Dengan konsep ini diharapkan ada koeksistensi antara hukum adat (folks law) dengan hukum negara (state law). Adalah relevan dengan sesanti Bhineka Tunggal Ika yang secara de facto mencerminkan kemajemukan budaya bangsa dalam naungan Negara Kesatuan Republik Indonesia. ${ }^{1}$ Dalam hubungannya dengan tujuan hukum, tidak hanya diarahkan untuk menjaga keteraturan dan ketertiban sosial (social order) yang fungsinya tidak hanya sebagai instrumen pengawasan sosial (social control), tapi juga dikembangkan sebagai alat untuk merekayasa kehidupan sosial (social engineering) untuk mewujudkan nilai kepastian hukum, namun fungsi hukum juga ditingkatkan agar dapat memainkan peran sebagai instrumen untuk memelihara dan memperkokoh integrasi bangsa dalam masyarakat yang bercorak multikultural. ${ }^{2}$

Secara filosofis pembentukan UUPA ditujukan untuk mewujudkan apa yang digariskan dalam Pasal 33 ayat (3) UUD1945, yaitu mewujudkan kesejahteraan seluruh rakyat Indonesia dalam arti kesejahteraan lahir batin, adil dan merata bagi seluruh rakyat Indonesia. ${ }^{3}$ Dalam kenyataannya ketentuan konversi dalam UUPA justru rentan menimbulkan konflik sampai saat ini, seperti kasus Lemukih Buleleng,

${ }^{1}$ I Nyoman Nurjaya, Pengelolaan Sumber Daya Alam Dalam Perspektif Antropologi Hukum, Cetakan I. Kerjasama Program Magister Ilmu Hukum Program Pascasarjana Unibraw, ARENA HUKUM Majalah Fakultas Hukum Universitas Brawijaya dengan Penerbit Universitas Negeri Malang, Malang, UM PRESS, 2006, hlm. 1.

${ }^{2}$ Ibid., hlm. 2.

${ }^{3}$ Mohammad Hatta, Hukum Tanah Nasional Dalam Perspektif Negara Kesatuan, Cetakan I, Yogyakarta, Media Abadi, 2005, hlm. 1. 
kasus laba pura di Desa Adat Culik dan tapal batas di Karangasem, kasus tanah setra di Desa Adat Tohpati Kungkung, kasus tanah ayahan desa (AYDS) dan pekarangan desa (PKD) di Desa Adat Tamanbali Bangli dan Tusan Klungkung, kasus loloan di Desa Adat Canggu Badung, kasus pembongkaran pura di Desa Adat Intaran Sanur Denpasar (Bali Post 2006-2010).

\section{Rumusan Masalah}

Mencermati latar belakang sebagaimana diuraikan di atas, akan dikaji dampak ketentuan konversi dalam UUPA terhadap hak penguasaan dan pemilikan tanah adat.

\section{Tujuan Penelitian}

Penelitian ini dimaksudkan untuk mencermati dan menganalisis dampak dari ketentuan konversi dalam UUPA terhadap status tanah adat di Bali.

\section{Metode Penelitian}

Kajian dalam masalah ini menggunakan penelitian hukum normatif atau penelitian hukum doktrinal, ${ }^{4}$ dengan pendekatan perundang-undangan atas pertimbangan masih ada kekosongan norma, dan kekaburan norma dalam UUPA. Juga dipergunakan pendekatan analitis untuk mengetahui makna istilah-istilah yang ada sekaligus mengetahui kontekstualnya. ${ }^{5}$ Sedangkan bahan hukum dalam penelitian ini dikumpulkan dengan studi dokumentasi, dan pencatatan dengan sistem file, selanjutnya dianalisis dengan model hermeneutics analisys. ${ }^{6}$

${ }^{4}$ Ronny Hanitijo Soemitro, Metodologi Penelitian Hukum, Jakarta, Cetakan Pertama, Ghalia, 1983, hlm. 9. 5Johnny Ibrahim, Teori \& Metodologi Penelitian Hukum Normatif. Edisi Revisi, Malang Jawa Timur, Cetakan Kedua, Bayumedia Publishing, 2006, hlm. 98.

'Jazim Hamidi, Hermeneutika Hukum, Teori Penemuan Hukum Baru dengan Interpretasi Teks, Cetakan Pertama, Yogyakarta, UII Press, 2005, hlm. 45. Lihat juga Earl Babbie, The Basics of Social Research, Amerika, Wadsworth Publishing Company, 1999, p. 260. 


\section{Hasil dan Pembahasan}

\section{Penguasaan Tanah Adat}

Falsafah yang mendasari hukum adat mengenai tanah adalah konseptual komunalistik religius, karena dalam konsep hukum adat kehidupan individu dipandang sebagai kehidupan yang terutama diperuntukkan buat mengabdi kepada kehidupan masyarakat. ${ }^{7}$

Tanah adat sebagai hak kepunyaan bersama dari suatu masyarakat hukum adat dipandang sebagai tanah bersama yang merupakan "pemberian/anugerah" dari suatu kekuatan gaib, sehingga semua hak perorangan bersumber dari tanah bersama tersebut. IB. Lasem menyebutkan, bahwa tanah-tanah adat seperti Pekarangan Desa (PKD), Ayahan Desa (AYDS) yang dikuasai secara individu di dalamnya terkandung konsep Tri Hita Karana, yaitu berupa Parhyangan yang berwujud Merajan (believe system), Pelemahan yang berwujud wilayah perumahan (artefact system), dan Pawongan yang berwujud anggota keluarga yang tinggal di situ (social system) yang notabene sebagai krama banjar dan krama desa adat. Semuanya ini sudah barang tentu diatur dalam awig-awig. ${ }^{8}$ Jadi penguasaan tanah adat ini secara ekonomis tidak hanya dimanfaatkan untuk meningkatkan kesejahteraan secara pribadi pemegangnya, tapi juga diabdikan untuk kepentingan bersama dalam bentuk pelaksanaan kewajiban berupa "ayahan" yang mempunyai dimensi sosial dan religius (Desa adat dengan Parhyangan, seperti pura Kahyangan Tiga). Dengan demikian implementasi konsep komunal religius akan sangat nyata dapat disaksikan terhadap status tanah adat yang dikuasai oleh individu sebagai krama (anggota) desa adat.

Herman Soesang Obeng menyebutkan, bahwa pemilikan secara individual timbul apabila syarat de facto berupa bertempat tinggal dalam masyarakat hukum, mengerjakan tanah secara terus menerus, dan syarat de jure berupa pengakuan masyarakat akan pemilikan tersebut, berlaku secara bersamaan dalam diri pribadi yang bersangkutan. ${ }^{9}$

${ }^{7}$ Oloan Sitorus, Kapita Selekta Perbandingan Hukum Tanah, Yogyakarta, Cetakan Perdana,Mitra Kebijakan Tanah Indonesia, 2004. Lihat juga Supomo, R. Hubungan Individu dan Masyarakat dalam Hukum Adat, Jakarta, Cetakan ke-4, Pradnya Paramita, 1983.

${ }^{8}$ I MadeSuwitra, "Eksistensi Hak Penguasaan dan Pemilikan Atas Tanah Adat di Bali dalam Perspektif Hukum Agraria Nasional”, Disertasi (Program Doktor ilmu Hukum Fakultas Hukum Universitas Brawijaya, Malang. 2009), hlm. 52.

${ }^{9}$ Herman Soesang Obeng, Pertumbuhan Hak Milik Individuil Menurut Hukum Adat Dan Menurut UUPA Di Jawa Timur, Majalab Hukum. II (3), 1975, hlm. 51. 
Tanah-tanah adat sebagai tanah ulayat di Bali merupakan tanah bersama yang dikuasai dan dimiliki oleh desa adat secara komunal. Sebagian tanah komunal ini penguasaannya diserahkan (di-derivatif) kepada krama (anggota) desa adat secara individual yang disebut sebagai hak milik tidak penuh seperti PKD, AYDS. Menurut Grotius, bahwa milik pribadi dikonsepsikan mempunyai hak untuk memiliki dan menggunakan secara pribadi. Jadi ada milik bersama tetapi dapat digunakan untuk kepentingan pribadi. ${ }^{10}$

Beberapa sifat yang menonjol tentang pemilikan secara individu menurut hukum adat antara lain:

1. Pemilikan tanah hanya dapat dipunyai oleh warga masyarakat hukum saja (krama desa adat).

2. Pemilikan tidak lahir berdasarkan keputusan atau izin kepala adat. Keputusan atau izin kepala adat hanya berfungsi sebagai pembuka jalan ke arah kemungkinan menguasai tanah dengan hak milik. Pemilikan lahir berdasarkan pengakuan masyarakat yang disebabkan oleh kenyataan erat tidaknya hubungan seseorang atas tanah. Erat dalam arti tanah senantiasa dikerjakan, dirawat dengan baik dan tidak diabaikan.

3. Pemilikan hanya timbul apabila syarat de facto berupa tempat tinggal dalam masyarakat hukum, mengerjakan tanah secara terus menerus, dan syarat de jure berupa pengakuan masyarakat akan pemilikan tersebut, berlaku secara bersamaan dalam diri pribadi yang bersangkutan.

4. Berakhirnya hak milik atas tanah, berarti berhentinya pengakuan masyarakat atas hak orang yang bersangkutan. ${ }^{11}$

Dua unsur utama yang memberikan ciri khas hak ini yakni, pertama: tiadanya kekuasaan untuk memindahkan tanah, dan kedua, terdapat interaksi antara hak komunal dan hak individu yang mempunyai akibat atau berlaku ke dalam maupun berlaku ke luar. ${ }^{12}$

Di Bali hak penguasaan tanah juga dilandasi oleh hak ulayat atau hak prabumian. Kondisi ini akan sangat relevan jika dikaitkan antara hubungan terjadinya desa adat dan tanah adat dalam perspektif sejarahnya. Di samping itu relevan juga dengan

\footnotetext{
${ }^{10}$ A. Sonny Keraf, Hukum Kodrat \& Teori Hak Milik Pribadi, Yogjakarta, Kanisius, 1997, hlm. 59.

${ }^{11}$ Herman Soesangobeng, 1975, Op., Cit, hlm. 52.

${ }^{12}$ R. Van Dijk, Pengantar Hukum Adat Indonesia.,Terjem. A. Soehardi, Bandung, Cetakan ke delapan, Sumur Bandung, 1982, hlm. 56.
} 
teori hukum alam dan accupatio dalam arti adanya penguasaan dan pemilikan bersama (komunal) dan juga penguasaan dan pemilikan secara individual (perseorangan). Hubungan antara hak komunal dengan hak individual juga nampak saling mendesak, menebal dan menipis, mulur-mungkret. Bahkan lebih didominasi oleh hak individual, terutama dalam pemanfaatan tanah pekarangan beserta telajakannya. ${ }^{13}$ Proses menebal dan menipisnya hubungan hak komunal dengan hak individu itu nampaknya sangat bergantung pada kepekaan prajuru adatnya dan kesadaran krama desa terhadap tanah-tanah adat yang dikuasainya dalam menentukan apakah hak milik individu tidak penuh akan berubah statusnya menjadi hak milik individu penuh, karena di beberapa desa adat seperti di Desa Adat Kemenuh Gianyar, Desa Adat Tamanbali Bangli, Desa Adat Ngis Culik Karangasem sudah terjadi peralihan status dari tanah adat yang dikuasai individu (PKD atau AYDS) kemudian menjadi tanah individu penuh berdasarkan konversi.

Desa adat dalam hal ini tampaknya belum memahami implikasi adanya konversi dari AYDS menjadi tanah individu penuh, dan saat ini baru sadar, karena AYDS pada dasarnya nutug (mengekor) pada PKD, artinya segala keperluan bahan upakara dan upacara keagamaan biasanya berasal dan dihasilkan dari tanah AYDS yang disebut teba atau juga sebagai sumber bahan kebutuhan pokok jika tanah AYDS berupa tanah sawah. Bahkan tempat kegiatan yang berhubungan dengan aktivitas adat dapat dilakukan di teba (AYDS) sebagai nista mandala (teben) sesuai dengan konsep Tri Mandala. ${ }^{14}$ Tanah-tanah adat ini disebutkan sebagai "druwe" atau "druwen" desa (adat), berarti gelah (Bali) atau kepunyaan, milik, kekuasaan desa adat (IW. Simpen, 1985: 60). Jadi tanah-tanah yang ada dalam wilayah (wewengkon) desa adat merupakan druwe (n) desa, kecuali tanah pribadi penuh. Jadi dari konsep druwe ini, tanah-tanah adat sebagai tanah ulayat ada dalam kekuasaan desa adat, konsekuensinya muncul wewenang untuk mengurus dalam arti memelihara dan memimpin peruntukannya, juga yang secara langsung memanfaatkan untuk kepentingan umum, seperti untuk setra, pasar desa, balai desa.

Penguatan hubungan antara desa adat dengan tanahnya itu, kemudian dibuatkan aturan yang kemudian disuratkan dalam awig-awig yang melarang adanya

${ }^{13}$ I Made Suwitra, "Tugas Prajuru Adat dalam mengatur tanah adat khususnya tanah telajakan dalam konsep menuju Bali yang ajeg”, Jurnal Kertha Wicaksana, Fakultas Hukum Universitas Warmadewa, Denpasar, No. 11, 2005, hlm. 15.

${ }^{14}$ Afirmasi dengan IB. Lasem tanggal 7 Agustus 2008. 
pengalihan hak atau jual beli tanah druwe desa kepada orang yang bukan sebagai krama desa setempat, juga dilarang untuk mengagunkan tanah dimaksud, kecuali dipergunakan sesuai dengan tujuan (petitis) seperti yang tercantum dalam awig-awig dan memperoleh persetujuan melalui paruman desa. Salah satu awig desa adat seperti dalam Pawos 28 Awig-awig Desa Adat Ngis ditegaskan: "Tan kalugra ngadol miwah ngantahan sekancan padruwen desa, sejawaning kagunayang manut petitis tur polih pemutus sejeroning perarem desa" (dilarang menjual atau mengagunkan semua milik desa, kecuali digunakan sesuai dengan tujuan yang ada dalam awig dan telah mendapat persetujuan melalui paruman desa).

Hubungan yang erat antara desa adat dengan tanah adatnya yang bersifat religio magis ini nampak sekali sejak awal, yaitu sebelum dilakukan perabasan hutan pada saat kedatangan Maha Yogi Markandya yang ke dua, diadakan upacara keagamaan Bhuta Yadnya dengan menanam pancadatu di kaki Gunung Agung yang sekarang dikenal dengan Pura Basukian di Besakih, adanya tempat suci yang sekarang dikenal dengan Kahyangan Tiga sebagai unsur esensial di setiap desa adat. Adanya tempat suci yang disebut sanggah atau merajan pada setiap pekarangan rumah krama desa. Di setiap setra juga ada tempat sucinya yang disebut Pura Prajapati. Sedangkan di setiap pasar ada Pura Melanting.

Secara umum hak penguasaan atas tanah atau yang juga disebut hak atas tanah adalah hubungan hukum yang memberi wewenang untuk berbuat sesuatu atas tanah itu. Hak penguasaan atas tanah ini dapat dipakai dalam arti fisik dan yuridis. Pengertian penguasaan dan menguasai di sini dapat berdimensi perdata dan publik, namun pemilahan secara tegas tidak dikenal dalam hukum adat. Penguasaan dalam dimensi perdata adalah penguasaan yang memberi "wewenang untuk mempergunakan" tanah yang bersangkutan, sedangkan penguasaan dalam dimensi publik, memberi "wewenang kepada pemegangnya (desa adat) untuk mengurus dan mengatur" tanah (wilayah) yang dikuasainya. ${ }^{15}$

Menurut konsepsi di atas, maka yang dimaksudkan dengan hak penguasaan atas tanah adalah adanya hubungan hukum antara pemegang hak dan tanahnya. Oleh karena itu perlu dipahami terhadap siapa subjek atau pemegang hak atas tanah yang bersangkutan dan apakah nama objek atau tanah yang dipegang tersebut. ${ }^{16}$

${ }^{15}$ K Oka Setiawan, Hak Ulayat Desa Adat Tenganan Pegrinsingan Bali Pasca UUPA. Cetakan I, Disertasi Program Pascasarjana Fakultas Hukum Universitas Indonesia, Jakarta, 2003, hlm. 105.

${ }^{16}$ Ibid. 
Dari konsep ini dapat dinyatakan, bahwa hak penguasaan atas tanah oleh desa adat di Bali dapat dikelompokkan menjadi dua kelompok utama, yaitu: Hak milik individu tidak penuh dan hak milik komunal. Secara rinci menurut pengamatan penulis, dapat digambarkan dalam bagan sebagai berikut:

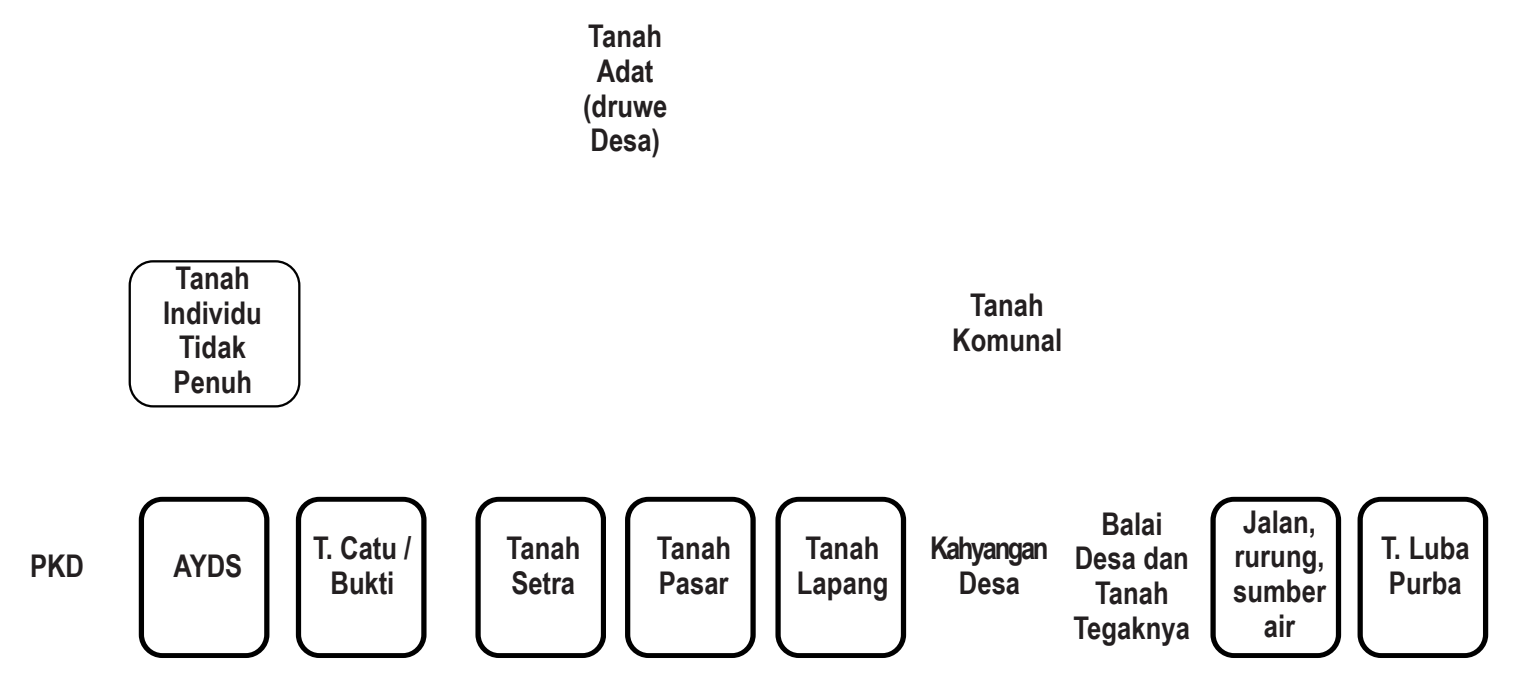

Konsep komunal religius dalam penguasaan dan pemilikan tanah adat ada dalam ikatan kemasyarakatan dalam bentak "ayph pan" yang mempunyai dimensi sosial dan religius, artinya pemegang ta hah adat diikat oleh kewajiban untuk mengabdi kepada banjar dan desa adatnya di satu sisi, sedangkan di sisi lain wajib berbakti kepada Tuhan Yang Maha Esa melalui ayahan ke pura.

Tanah individu tidak penuh berupa PKD, AYDS, tanah Catu atau bukti penguasaannya dilakukan secara individu layaknya hak milik, karena bersifat turun temurun, artinya hak penguasaan desa akan muncul kembali jika tanah adat yang dikuasai diterlantarkan atau dicabut (PKD, AYDS). Oleh karena itu setiap individu secara pasti selalu ingin menjalin hubungan secara baik dengan banjar atau desa adatnya sebagai persekutuannya. Sedangkan untuk tanah komunal, desa adat dapat menggunakan, memanfaatkan atau mengatur peruntukannya untuk kepentingan bersama. Sampai saat ini desa adat belum ditunjuk sebagai subjek hukum yang dapat mempunyai hak milik. Sedangkan secara ipso facto desa adat mempunyai (druwe) tanah sebagai satu kesatuan wilayahnya (pelemahan). Jadi masih ada hak menguasai desa adat. 


\section{Dampak Ketentuan Konversi terhadap Penguasaan Tanah Adat}

Pasal II Ketentuan konversi UUPA menentukan:

(1) hak-hak atas tanah yang memberi wewenang sebagaimana atau mirip dengan hak yang dimaksud dalam Pasal 20 ayat (1) seperti yang disebut dengan nama sebagai di bawah, yang pada mulai berlakunya Undang-undang ini, yaitu: hak agrarisch eigendom, milik, andarbeni, yasan, hak atas druwe, Hak atas druwe desa, jeseni, grant, Sultan, landerijenbezitrecht, altijddurende erfpacht, hak usaha atas bekas tanah partikelir dan hak-hak lain dengan nama apapun juga yang akan ditegaskan lebih lanjut oleh Menteri Agraria, sejak mulai berlakunya Undang-undang ini menjadi hak milik tersebut dalam Pasal 20 ayat (1), kecuali jika yang mempunyainya tidak memenuhi syarat sebagai yang tersebut dalam Pasal 21;

(2) Hak-hak tersebut dalam ayat (1) kepunyaan orang asing, warga negara yang di samping kewarganegaraan Indonesia mempunyai kewarganegaraan asing dan badan hukum yang tidak ditunjuk oleh Pemerintah sebagai yang dimaksud dalam Pasal 21 ayat (2) menjadi hak guna usaha atau hak guna bangunan sesuai dengan peruntukan tanahnya, sebagai yang akan ditegaskan lebih lanjut oleh Menteri Agraria.

Tanah-tanah adat di Bali yang dikenal dengan tanah-tanah ayah atau druwe desa sesuai dengan ketentuan Pasal II konversi dari UUPA disebut dengan tanah hak atas druwe atau tanah hak atas druwe desa. Tanah druwe desa ini terdiri dari tanah setra, tanah pasar, tanah laba pura, tanah PKD, tanah AYDS, sumber air (kelebutan toya), loloan, pantai.

Dari tanah adat ini, nampak ada tiga subjek hak yang dapat melakukan permohonan konversi menjadi tanah hak milik, yaitu: desa adat, pura, krama (anggota) desa adat. Jika Tanah-tanah adat berupa PKD dan AYDS semuanya dikonversi menjadi hak milik (pribadi penuh), lama kelamaan akan dapat mengaburkan sifat ayahan yang melekat pada tanah adat itu. Secara normatif eks pemegang tanah adat dimaksud, tidak lagi dibebani kewajiban (ayahan) dan sifat komunal religius dari tanah tersebut juga akan hilang. Awig-awig desa adat tidak lagi mempunyai kewenangan untuk mengaturnya. Pada gilirannya eks tanah-tanah adat ini dapat dialihkan kepada orang "asing" (bukan krama desa) di luar pengawasan kepala adat (prajuru adat). Bila Ini terjadi berarti bertentangan dengan hukum agama masyarakat hukum adat yang bersangkutan seperti yang diatur dalam Pasal 5 UUPA, karena 
eks tanah adat dapat saja dimiliki oleh orang-orang yang tidak mampu melakukan ayahan ke desa adat karena terkait dengan Kahyangan Tiga dan pura lainnya terutama ayahan tenaga. Kecuali jika semua ayahan fisik itu dapat diganti dengan "uang". Kondisi ini akan semakin parah jika semua pemegang atau pemilik tanah-tanah eks tanah adat (PKD dan AYDS) membayar ayahan ke desa atau ke pura desa.

Konversi tanah AYDS atau PKD di beberapa desa adat tampaknya disambut baik oleh masyarakat hukum adat, terutama oleh pihak yang kebetulan menguasai tanah adat dimaksud dengan berbagai latar belakang, seperti yang terjadi di Desa Adat Tamanbali Bangli melalui Proyek Operasi Nasional Agraria (PRONA) Provinsi Bali Tahun 1985/1986, seperti tabel di bawah ini:

Tabel

Konvensidi Desa Tamanbali Bangli 1985/1986

\begin{tabular}{|c|c|c|c|c|c|}
\hline $\mathrm{No}$ & Pemohon & Letak/Subak & $\begin{array}{l}\text { No.Pipil, } \\
\text { Persil, kls }\end{array}$ & Jenis Tanah & $\begin{array}{l}\text { Luas } \\
\text { (m2) }\end{array}$ \\
\hline 1 & Ni W Rabed & Ds. Tamanbali No.56 a & $355,135, \mathrm{I}$ & PKDPerumahan & 850 \\
\hline 2 & I W Saju & $\begin{array}{l}\text { Br. KawanKel. Kawan } \\
\text { Bangli. }\end{array}$ & $89,24, \mathrm{I}$ & AYDSPertanian & 5200 \\
\hline 3 & $\begin{array}{l}\text { I Ngh DuniaI } \\
\text { Nym Kereg }\end{array}$ & $\begin{array}{l}\text { Br. SiladanDs Tamanbali } \\
\text { 56a Bangli }\end{array}$ & $185,129, \mathrm{I}$ & PKDPerumahan & 1400 \\
\hline 4 & I Nym Kerta & $\begin{array}{l}\text { Br. SiladanDs Tamanbali } \\
\text { 56a Bangli }\end{array}$ & $88,130, \mathrm{I}$ & Pertanian & 300 \\
\hline 5 & I K Bigbig & $\begin{array}{l}\text { Br. SiladanDs Tamanbali } \\
\text { 56a Bangli }\end{array}$ & $445,23, \mathrm{I}$ & AYDSPertanian & 700 \\
\hline
\end{tabular}

Sumber : Lampiran pengumuman pertama persertifikatan hak atas tanah pada Proyek Operasi Nasional (PRONA) Agraria Provinsi Bali Tahun 1985/1986.

Di desa adat lain di Bali, konversi tanah-tanah adat ini juga tidak dapat dihindarkan, seperti yang terjadi di Desa Adat Kemenuh Gianyar. Sedangkan tanah PKD masih ada. Di samping itu juga terjadi di Desa Adat Ngis, Desa Adat Culik Karangasem terutama terhadap tanah AYDS yang dikuasai oleh krama inti (anggota desa adat inti). ${ }^{17}$ Walaupun telah disertifikatkan, status ayahan masih melekatinya, sehingga pada setiap kegiatan upacara keagamaan di desa adat, krama inti mempunyai

${ }^{17}$ I Made Suwitra, 2009, Op.Cit., hlm. 208 
tanggung jawab penuh dibandingkan dengan krama biasa yang lainnya yang tidak memegang tanah AYDS.

Saat ini memang status ayahan pada AYDS yang sudah disertifikatkan masih ada, namun sejarah perjalanan waktu akan terus mengujinya, apakah status ayahannya akan dapat tetap melekatinya, apabila sudah ada pergantian generasi yang secara pasti akan terjadi, karena tanah dimaksud akan diterima lanjutkan (diwariskan) kepada generasi berikutnya yang sudah barang tentu tidak tahu asal usul tanah yang diterima tersebut.

Secara riil akan tampak hak individu menjadi semakin kuat, sedangkan hak komunal (desa adat) menjadi melemah, dan bahkan hilang sama sekali, yaitu relevan dengan konsep mulur-mungkret seperti diungkapkan Iman Sudiyat.

Maksud dari ketentuan konversi ini memang ditujukan untuk dapat lebih menjamin nilai kepastian hukum terhadap hak atas tanah, di mana UUPA memang lebih kental mengarah pada nuansa individualisasi terhadap hak milik atas tanah. Ketentuan ini tampaknya akan kontradiktif apabila dibandingkan dengan Konsiderans/Berpendapat dan Pasal 5 dari UUPA itu sendiri yang mengakui hukum adat sebagai sumber utama dan juga sebagai pelengkap dalam pembentukan HTN.

Berbeda dengan maksud ketentuan Pasal 3 UUPA, di mana pelaksanaan hak ulayat dan hak-hak yang serupa itu dari masyarakat-masyarakat hukum adat, sepanjang menurut kenyataannya masih ada, harus sedemikian rupa. Ini mengindikasikan, bahwa negara mengakui eksistensi hak ulayat masyarakat hukum adat jika memang dalam kenyataannya masih ada, sehingga hak komunal masih diakui dengan catatan tidak bertentangan dengan kepentingan nasional dan negara. Namun apabila semua tanah adat atau tanah ayah (PKD dan AYDS) dikonversi menjadi hak milik pribadi penuh, berarti akan terjadi pembatasan berlakunya hak ulayat desa yang selanjutnya tidak mungkin untuk dihidupkan lagi (Pasal 3 Peraturan Menteri Agraria No.5/1999).

Memang di satu sisi, UUPA berfungsi sebagai sarana merekayasa masyarakat (a tool of social engineering) yang diharapkan dapat membawa perubahan pada perilaku hukum warga masyarakat, yaitu terutama pada sistem pendaftaran tanah (rechtskadaster). Sarana pembaharuan ini akan sangat tepat apabila untuk pendaftaran tanah-tanah adat ini tidak dilakukan dengan melakukan perubahan terhadap subjek haknya atau tidak merubah status tanah adat dimaksud. Artinya subjek hak yang akan mendaftarkan tanah-tanah adat ini tetap dilakukan oleh desa adat. Sedangkan 
untuk tanah adat yang dikuasai individu (tanah pribadi tidak penuh) selayaknya status tanahnya tidak ikut berubah, apakah sebagai PKD atau AYDS atau dengan kata lain identitas tanahnya baik sebagai PKD atau AYDS tidak dihilangkan setelah diadakan konversi dan dicarikan padanannya dalam UUPA, seperti Hak Pakai (HP) untuk AYDS, dan HGB untuk PKD yang diletakkan di atas Hak Milik atau Hak Pengelolaan (HPL) desa adat sebagai masyarakat hukum adat (Pasal 2 Ayat (4) UUPA), sehingga UUPA dengan hukum adat secara riil dapat berkoeksistensi dan kepentingan pribadi (private interest).

Fungsi hukum sebagai sarana rekayasa atau pembaharuan dari UUPA baru dapat dilaksanakan sebatas tanah laba pura, yaitu dengan ditunjuknya pura sebagai badan hukum yang dapat memiliki hak atas tanah sesuai dengan PP Nomor 38 Tahun 1963 jo Keputusan Menteri Dalam Negeri No. SK.556/DJA/1986. Oleh karena sejak 1986 persekutuan pengempon pura baru dapat mendaftarkan tanah laba puranya atas nama pura, di mana sebelumnya ada yang didaftarkan atas nama pribadi prajuru (pengurus) pura atau pribadi pemangku (petugas keagamaan yang khusus diangkat di pura yang bersangkutan).

Sebenarnya sejak dikeluarkannya UUPA masyarakat hukum adat di Bali baik secara komunal maupun secara individual berkehendak untuk dapat mendaftarkan hak atas tanahnya yang selama ini dikuasainya baik secara de facto maupun secara de jure dalam konsep hukum adat, sehingga akhirnya mendapatkan sertifikat. Kenyataan ini memang dapat dijadikan dasar permohonan hak, seperti keterangan sporadik yang dibuat oleh Kepala Desa Dinas. ${ }^{18}$

Desa adat di Bali sebagai salah satu persekutuan hukum yang ada di wilayah negara Republik Indonesia mempunyai karakteristik yang sangat khas dibandingkan dengan persekutuan lainnya terutama dari ciri komunal religio magisnya, sehingga jika dikaitkan dengan ketentuan Pasal 1 huruf c, dan d PP No. 38 Tahun 1963, yang secara limitatif menegaskan, bahwa badan-badan hukum yang dapat mempunyai hak milik atas tanah antara lain: badan-badan keagamaan, yang ditunjuk oleh Menteri Pertanian/Agraria setelah mendengar Menteri Agama, dan Badan-badan sosial, yang ditunjuk oleh Menteri Pertanian/ Agraria setelah mendengar Menteri Kesejahteraan Sosial, maka desa adat telah memenuhi kriteria sebagai badan sosial yang religius. Namun sampai saat ini belum ditunjuk sebagai badan hukum yang dapat memiliki hak atas tanah.

${ }^{18}$ I Made Suwitra, 2009, Op.Cit., hlm. 211. 
Mencermati pada kondisi di atas, dapat dinyatakan bahwa dampak positif dari adanya ketentuan tentang konversi dari UUPA adalah dapat lebih menjamin adanya kepastian hukum terhadap hak penguasaan dan pemilikan tanah, sehingga juga berdampak pada adanya kepastian terhadap perlindungannya.

Di samping itu, ketentuan konversi ini juga mempunyai dampak negatif, yaitu adanya sekularisasi dan individualisasi terhadap penguasaan dan pemilikan tanahtanah adat yang dulunya bersifat komunal religius. Penguasaannya tidak lagi diikat oleh sistem "ayahan" dalam persekutuan (desa adat) tapi sudah terlepas dari akar budayanya, akhirnya dapat memunculkan sikap eksklusivisme pemiliknya terutama dalam pengasingannya, karena tidak tunduk lagi pada ketentuan hukum adat setempat (awig-awig desa adat).

Bahaya akan semakin dekat jika desa adat tidak segera sadar dan tidak cerdas menyikapinya, karena selama ini proses konversi hanya melibatkan pemerintahan desa dinas, padahal tanah-tanah yang dikonversi itu merupakan tanah-tanah adat sebagai tanah ulayat yang seharusnya tunduk pada ketentuan hukum adat dan struktur pemerintahan desa adat. Proses pengumuman sebagai pelaksanaan asas publisitas dalam UUPA hanya merupakan lembar pengumuman yang dibuat oleh Kantor Pertanahan yang ditujukan kepada Kepala Desa (dinas) letak tanah dimaksud untuk ditempelkan. Namun jika mau dipahami corak hukum adat di Bali, sebenarnya pelaksanaan pengumuman ini dapat dipadukan dengan lembaga "siar" yang dikenal dalam hukum adat sebagi perwujudan corak terang, di mana proses "siar" dapat dilakukan dalam paruman di desa adat atau di banjar yang biasanya diadakan setiap bulan (35 hari dalam hitungan Bali).

Tanah sebagai wilayah merupakan salah satu unsur esensial dari persekutuan (desa adat), sehingga apabila dilakukan konversi, hendaknya tidak sampai menghilangkan status tanah dan subjek pemegang haknya, sehingga terjadi koeksistensi kekuatan antara UUPA sebagai hukum nasional dengan hukum adat sebagai hukum lokal, sehingga kata "berdasar" dan "ialah" hukum adat dimaksudkan agar sifat pendaftaran dalam UUPA mampu mengadopsi filosofi adat dan taat asas. ${ }^{19}$

${ }^{19}$ Herman Soesangobeng, "Pendaftaran Tanah Ulayat di Sumatera Barat dengan Contoh Pilot Proyek Pendaftaran Tanah di Desa Tiga Jangko, Kecamatan Lintau Buo, Kabupaten Tanah Datar”, Himpunan Makalah dan Rumusan Workshop Tanah Ulayat di Sumatera Barat yang diselenggarakan oleh Kantor Wilayah Badan Pertanahan Nasional Propinsi Sumatra Barat pada Tanggal 23-24 Oktober 2000di Padang. H. Syofyan Jalalludin. Ed. Kepala Kantor Wilayah BPN Provinsi Sumatera Barat. 2000, hlm. 117. 


\section{Penutup}

Terjadinya konversi tanah-tanah adat menjadi tanah individu penuh berdampak pada hilangnya status "ayahan" yang melekati tanah adat tersebut. Kondisi ini, saat ini telah menimbulkan berbagai konflik pertanahan di setiap kabupaten. Oleh karena itu perlu diupayakan secara riil oleh semua pihak agar dalam mencari padanan model penguasaan dan pemilikan tanah adat melalui konversi tidak sampai menghilangkan status "ayahan" yang melekatinya sehingga negara di satu sisi dapat menghormati keberadaan tanah-tanah adat dari desa adat sebagai masyarakat hukum adat, dan di sisi lain tidak muncul sifat eksklusivisme dari masyarakat hukum adat, sehingga terjadi koeksistensi antara hukum negara dan hukum adat terhadap hak penguasaan dan pemilikan tanah adat, Desa adat sudah saatnya diberikan hak pengelolaan seperti yang diberikan kepada Pemerintah Daerah menurut ketentuan Pasal 2 ayat (4) UUPA, sehingga hak yang diterbitkan kepada pemegang tanah adat tidak menghilangkan status "ayahan" yang melekatinya.

\section{Daftar Pustaka}

Babbie, Earl, The Basics of Social Research, Wadsworth Publishing, Amerika, Company, 1999.

Boedi Harsono, Hukum Agraria Indonesia Sejarah Pembentukan UUPA Isi dan Pelaksanaannya, Jilid I Hukum Tanah Nasional, Jakarta, Cetakan Kesembilan (Edisi revisi), Djambatan, 2003.

Dijk, R. Van, Pengantar Hukum Adat Indonesia, Terjem. A. Soehardi, Bandung, Cetakan ke delapan, Sumur Bandung, 1982.

H. Mohammad Hatta, Hukum Tanah Nasional dalam Perspektif Negara Kesatuan, Yogyakarta, Cetakan I, Media Abadi, 2005.

Herman Soesang Obeng, “Pendaftaran Tanah Ulayat di Sumatera Barat dengan Contoh Pilot Proyek Pendaftaran Tanah di Desa Tiga Jangko, Kecamatan Lintau Buo, Kabupaten Tanah Datar". Dalam Himpunan Makalah dan Rumusan Workshop Tanah Ulayat di Sumatera Barat yang diselenggarakan oleh Kantor Wilayah Badan Pertanahan Nasional Propinsi Sumatra Barat pada Tanggal 23-24 Oktober 2000 di Padang. H. Syofyan Jalalludin. Ed. Kepala Kantor Wilayah BPN Provinsi Sumatera Barat. 2000.

, Pertumbuhan hak milik individuil menurut hukum adat dan menurut UUPA di Jawa Timur, Majalah Hukum, II (3): 49-76. 1975.

, "Pendaftaran Tanah Ulayat di Sumatra Barat dengan contoh Pilot Proyek Pendaftaran Tanah di Desa Tiga Jongkok Kecamatan Lintau Buo Kabupaten 
Tanah Datar". Dalam Himpunan Makalah dan Rumusan Workshop Tanah Ulayat di Sumatra Barat. H. Sofyan Jalaluddin. Ed. Kantor Wilayah Badan Pertanhan Provinsi Sumstera Barat. 2000.

I Made Suwitra, “Eksistensi Hak Penguasaan dan Pemilikan Atas Tanah Adat di Bali dalam Perspektif Hukum Agraria Nasional". Disertasi. Program Doktor ilmu Hukum Fakultas Hukum Universitas Brawijaya, Malang, 2009.

,"Tugas Prajuru Adat dalam mengatur tanah adat khususnya tanah telajakan dalam konsep menuju Bali yang ajeg". Kertha Wicaksana. Fakultas Hukum Universitas Warmadewa, Denpasar, (11) 1, 2005.

I Nyoman Nurjaya, Pengelolaan Sumber Daya Alam dalam Perspektif Antropologi Hukum, Cetakan I. Kerjasama Progran Magister Ilmu Hukum Program Pascasarjana Unibraw, ARENA HUKUM Majalah Fakultas Hukum Universitas Brawijaya dengan Penerbit Universitas Negeri Malang (UM PRESS, Malang), 2006.

IW. Simpen, Kamus Bahasa Bali, Denpasar, PT. Mabhakti, 1985.

Johnny Ibrahim, Teori \& Metodologi Penelitian Hukum Normatif, Edisi Revisim, Cetakan Kedua, Malang Jawa Timur, Bayumedia Publishing, 2006.

Jazim Hamidi, Hermeneutika Hukum, Teori Penemuan Hukum Baru dengan Interpretasi Teks, Yogyakarta, Cetakan Pertamam, UII Press, 2005.

K. Oka Setiawan, "Hak Ulayat Desa Adat Tenganan Pegrinsingan Bali Pasca UUPA". Cetakan I. Disertasi. Program Pascasarjana Fakultas Hukum Universitas Indonesia, Jakarta, 2003.

Oloan Sitorus, Kapita Selekta Perbandingan Hukum Tanah, Cetakan Perdana, Yogyakarta, Mitra Kebijakan Tanah Indonesia, 2004.

dan H.M. Zaki Sierrad, Hukum Agraria di Indonesia Konsep Dasar dan Implementasi, Yogyakarta, Cetakan Perdana, Mitra Kebijakan Tanah Indonesia, 2006.

Ronny Hanitijo Soemitro, Metodologi Penelitian Hukum, Cetakan Pertama, Jakarta, Ghalia Indonesia, 1983.

Sonny Keraf A., Hukum Kodrat \& Teori Hak Milik Pribadi, Yogjakarta, Kanisius, 1997.

R. Supomo, Hubungan Individu dan Masyarakat dalam Hukum Adat, Cetakan ke-4. Jakarta, Pradnya Paramita, 1983.

Ketetapan MPR RI Nomor IX/MPR/2001 tentang Pembaharuan Agraria dan Pengelolaan Sumber Daya Alam.

Undang-Undang Dasar 1945 Perubahan pertama, kedua, ketiga, dan keempat.

Undang-Undang Nomor 5 Tahun 1960 tentang Peraturan Dasar Pokok-Pokok Agraria.

Peraturan Pemerintah No. 38 Tahun 1963 tentang Penunjukan Badan-Badan Hukum yang dapat mempunyai Hak Milik Atas Tanah.

Peraturan Pemerintah Nomor 24 Tahun 1997 tentang Pendaftaran Tanah. 
Peraturan Menteri Negara Agraria/Kepala Badan Pertanahan Nasional No. 5/1999 tentang Pedoman Penyelesaian Masalah Hak Ulayat Masyarakat Hukum Adat.

Surat Keputusan menteri Dalam Negeri No. SK 556/DJA/1986 tentang Penunjukan Pura sebagai Badan Hukum Keagamaan yang dapat mempunyai Hak milik Atas Tanah.

Peraturan Daerah Propinsi Daerah Tingkat I Bali Nomor 06 Tahun 1986 tentang Kedudukan, Fungsi dan Peranan Desa Adat sebagai Kesatuan Masyarakat Hukum Adat dalam Propinsi Daerah Tingkat I Bali

Peraturan Daerah Propinsi Bali Nomor 3 Tahun 2001 Jo Nomor 3 Tahun 2003 tentang Desa Pakraman.

Awig-Awig Desa Adat Ngis Kecamatan Manggis Kabupaten Karangasem, 1988. 